\title{
Kajian Peningkatan Sumber Daya Manusia Bidang Pemasaran Batik Jambi (Studi Kasus: Pengrajin Batik Jambi CV. Kreasi Batik Asmah)
}

\author{
Hario Tamtomo*, Wella Sandria \\ Universitas Muhammadiyah Jambi \\ *Correspondence email: h4rio.35@gmail.com, wellasandria@gmail.com
}

\begin{abstract}
The uniqueness of Jambi Batik can be seen from the type of batik patterned with Arabic calligraphy and fabric edges that adopted Chinese culture. To encourage the success of the batik business in Jambi, entrepreneurs must manage their human resources. This study aims to determine the management of human resources at CV. Kreasi Asmah Batik, located across the city of Jambi. This study uses a qualitative method with a SWOT analysis (Strengths, Weaknesses, Threats and Opportunities). The results showed that: 1) The factors that became the strength of CV. Batik Kreasi Asmah are good quality products, good batik techniques, specialization of unique motifs that are its own uniqueness. 2) Factors that can be used as opportunities for CV. Batik Kreasi Asmah are the increasing purchasing power and interest in batik products. 3) The most threatening factor in CV. Batik Kreasi Asmah are the increasing number of similar businesses with large capital originating from outside the province of Jambi and even produced in Java and resold in Jambi. 4) CV. Batik Kreasi Asmah are in a stable position in the attractiveness of the middle market and middle class market competition.
\end{abstract}

Keywords: Human Resources Management, Marketing, Quality Improvement.

\section{Pendahuluan}

Batik merupakan salah satu warisan budaya Indonesia yang memiliki keunggulan tersendiri yaitu pewarnaan batang warna. Di antara berbagai kesusastraan tradisional yang menggunakan teknik ini, tidak ada yang seindah dan sehalus batik (Doellah, 2002). Batik memiliki nilai filosofis yang tinggi dan sarat akan pengalaman yang transenden. Nilai inilah yang mendasari visualisasi akhir yang tampak pada komposisi batik itu sendiri. Secara teknis, motif batik dan batik Indonesia telah diakui dan ditetapkan oleh UNESCO sebagai warisan budaya dan non material (masterpiece of the oral and itangible heritage of human), sejak tanggal 2 Oktober 2009. Batik merupakan salah satu warisan bangsa Indonesia nantinya. nenek moyang. dikembangkan di berbagai wilayah tanah air dan dikenalkan oleh Presiden Soeharto pada saat konferensi PBB (Perserikatan Bangsa-Bangsa). Keragaman batik di Indonesia terus berkembang. Di Provinsi Jambi, tanah Pusako Betuah ini memiliki ciri khas batiknya yaitu motif yang mengisahkan daerahnya, selain terkenal dengan kualitasnya yang bagus. Keunikan batik Jambi yang mampu memadukan ornamen dari berbagai budaya terlihat dari jenis batik dengan motif kaligrafi Arab, serta tepian kain yang mengadopsi budaya Tionghoa. Hampir semua jenis batik yang ada saat ini di Indonesia semuanya sama, namun batik Jambi memiliki sedikit perbedaan yaitu pada corak dan warnanya. Saat ini jumlah ragam hias batik Jambi telah mencapai 50 jenis motif ragam hias batik (Lea, 2015).

Industri batik Jambi sangat berpengaruh terhadap minat wisatawan lokal maupun mancanegara, karena batik merupakan salah satu warisan budaya daerah khususnya batik tulis yang memiliki 40 motif khas Jambi (Sudewi, 2008). Batik Jambi sangat khas karena mengandalkan penuh 49 unit usaha kecil pengrajin, bukan yang bermodal besar. Sejak puluhan tahun lalu hingga sekarang, sebagian besar proses produksi batik Jambi dilakukan di rumahrumah. Alhasil, batik Jambi sangat menyatu dengan kehidupan masyarakatnya. Batik Jambi menjadi nafas keseharian warganya. Usaha batik Jambi ini semakin booming, namun kondisi tersebut tidak sejalan dengan bertambahnya jumlah unit usaha kerajinan tangan (Rahmat, 2010). Namun, bisnis batik Jambi saat ini sedang menghadapi masa transisi. Industri batik Jambi menyusut dalam lima tahun terakhir. Perkembangan dunia yang semakin kompleks dan munculnya negara-negara pesaing baru, seperti Vietnam, China, Malaysia, dan India, menantang industri batik Jambi untuk segera mentransformasikan dirinya ke arah yang lebih modern. Pekerja batik di Jambi kini didominasi oleh pengrajin rumah tangga, khususnya perempuan. Mereka kebanyakan berasal dari kalangan ibu rumah tangga lokal yang ingin mencari nafkah. Hidup mereka mungkin sepenuhnya bergantung pada pekerjaan membatik dan berbasis pada pengusaha kecil dan menengah.

Dalam perkembangannya, batik Jambi sempat terputus selama beberapa tahun dan pada pertengahan tahun 70 an ditemukan beberapa helai batik kuno milik salah satu pengusaha wanita "Ibu Ratu Mas Hadijah" dan dari situ batik Jambi mulai digalakkan kembali. Salah satu ibu yang turut membantu perkembangan batik di Jambi adalah Ibu Zainab dan Ibu Asmah yang memiliki ketrampilan membatik di Seluruh Kota. Pada awalnya pewarnaan batik Jambi masih menggunakan bahan alami dari tumbuhan yang terdapat di hutan Jambi, seperti: 1) Kayu Sepang menghasilkan warna kuning kemerahan, 2) Kayu Ramelang menghasilkan warna merah kecoklatan, 3) Kayu Lambato menghasilkan warna kuning warna, dan 4) Kayu Nilo menghasilkan warna biru. Warna-warna tersebut merupakan warna tradisional batik 
Jambi yang memiliki daya tarik tersendiri berbeda dengan pewarna kimia. Setelah itu, banyak masyarakat Jambi yang membuat kain sendiri dengan tenun, songket dan Alat Tenun Bukan Mesin (ATBM). Kegiatan tersebut tersimpan pada Arsip Jambi, menunjukkan ibu-ibu sedang menenun dengan ATBM sekitar tahun 1930 (Munawaroh, 2011).

Berdasarkan data Dinas Perindustrian dan Perdagangan Kota Jambi, pada tahun 2016 terdapat 745 koperasi dan 12.000 unit UMKM, di antaranya terdapat 57 unit Batik Jambi (Industri Kecil Menengah) yang tersebar di 4 desa di Kecamatan Danau Teluk dan Pelayanagan, Daerah Sekoja, Kota Jambi. . dengan penyerapan tenaga kerja mencapai 136 orang atau 2,27 tenaga kerja per unit usaha. Oleh karena itu, produk Batik Jambi merupakan produk unggulan daerah yang layak untuk diangkat dalam persaingan global (Disperindag Provinsi Jambi, 2016). Beberapa hal yang mempengaruhi penurunan produksi adalah lemahnya daya beli masyarakat, mahalnya bahan baku yang harus didatangkan dari Jawa, pembuatan pewarna alami untuk kayu lampato, kayu merlang, indigo hitam yang memakan waktu lama, penyediaan modal yang minim. dari Kementerian Perindustrian dan Perdagangan, hingga penampilan batik. percetakan dengan mesin cetak yang semakin membuat industri batik terpuruk bahkan mati. Itulah sebabnya sejak tahun 2000 batik tulis semakin ditinggalkan dan beralih ke batik cap yang harganya jauh lebih murah serta lebih cepat dan praktis (Azmiah, 2010). Sehingga, diperlukan terobosan baru dalam industri bisnis batik Jambi dengan strategi dan konsep bisnis yang baru karena adamya kelebihan kapasitas produksi di semua sektor usaha. Pasokan produk jauh melebihi permintaan konsumen. Konsumen menjadi sangat jarang bagi produsen yang mendorong persaingan ketat.

Namun, jika perusahaan berangkat dari kebutuhan konsumen individu dengan mengintegrasikan tiga bentuk manajemen; manajemen permintaan, manajemen jaringan dan manajemen sumber daya, perusahaan dapat melakukan aktivitas pemasarannya dalam 4 (empat) platform, yaitu penawaran pasar, aktivitas pemasaran, arsitektur bisnis, dan sistem operasi (Kotler \& Maesincee, 2002). Konsep ini menawarkan model pemasaran dinamis dengan mengacu pada integrasi rantai nilai, menggantikan prinsip membuat dan menjual dengan akal dan respons. Oleh karena itu roadmap SIDA Provinsi Jambi (Sistem Informasi Daerah) Produk Unggulan Batik Jambi disusun berdasarkan model integrasi bisnis dan pemasaran dengan periode 10 tahun (2016-2025) yang terbagi dalam 2 periode yaitu Periode Penguatan selama 5 periode. tahun (2016-2020) yang bertujuan untuk memperkuat daya saing produk Batik Jambi unggulan, dan Masa Perluasan selama 5 tahun (2012-2025) yang bertujuan untuk mendorong produk industri Batik Jambi yang berdaya saing menembus pasar nasional, daerah. dan pangsa pasar global. Setiap periode memuat 3 komponen program, yaitu 1) Penataan Pasar Input dengan program dan / atau kegiatan yang bertujuan untuk menjamin tersedianya input utama untuk proses produksi Batik Jambi yang mandiri dan berkelanjutan serta berbasis pemanfaatan sumber daya lokal yang ramah lingkungan, 2 ) Penataan Proses Produksi dengan program dan / atau kegiatan yang bertujuan untuk meningkatkan proses produksi oleh pelaku usaha dan diharapkan mampu meningkatkan kualitas dan daya saing produk Batik Jambi, dan 3) Penataan Pasar Produk dengan program dan / atau kegiatan bertujuan untuk memperkuat kemampuan produk Batik Jambi menembus pasar domestik, nasional maupun global atau dengan kata lain sebagai upaya memperluas pangsa pasar produk Batik Jambi (Disperindag Provinsi Jambi, 2016).

Untuk mendorong keberhasilan bisnis ini, para pengusaha (perusahaan) harus mampu mengelola berbagai sumber daya yang dimilikinya, salah satunya melalui Manajemen Sumber Daya Manusia (SDM). Sebagai sumber daya organisasi yang memiliki peran penting dalam pencapaian tujuan perusahaan, SDM harus dikelola agar mampu bersaing baik dalam jangka pendek maupun jangka panjang (Wilson, 2012). Apabila sumber daya manusia dikelola dengan baik maka penyelenggaraan industri khususnya di bidang pemasaran akan berjalan sesuai prinsip perusahaan yang pada akhirnya akan meningkatkan pendapatan perusahaan dan kemajuan industri batik di Jambi. Salah satu cara yang terkait dengan sumber daya manusia agar dapat menjadi sumber keunggulan kompetitif (competitive advantegae) adalah melalui peningkatan sumber daya manusia untuk dapat mengenali dan beradaptasi dengan lingkungan yang selalu berubah (Wilson, 2012).

Penulis mengamati, berbagai permasalahan dan tantangan yang harus dihadapi para pengrajin batik tersebut, salah satunya adalah kurangnya sumber daya manusia. Padahal, kualitas produk yang dihasilkan Jambi, misalnya, lebih baik dari kompetitor yang kebanyakan menggunakan motif batik printing. Selain itu, perajin masih harus berhadapan dengan rendahnya produktivitas dan keterampilan pekerja, kurangnya inisiatif pengrajin untuk melakukan inovasi produk, alat mesin penunjang proses produksi yang sudah usang dan daya beli masyarakat yang lemah. Diharapkan dengan adanya penelitian ini, industri batik Jambi memiliki sumber daya manusia yang handal sehingga dapat meningkatkan profesionalisme pekerja dan meningkatkan kualitas batik khas Jambi yang dapat menjadi ikon budaya daerah dengan nilai filosofis yang tinggi dan mampu bersaing di pasar bisnis nasional dan global. Penelitian ini bertujuan untuk melihat sejauh mana peningkatan SDM dalam pemasaran batik khas Jambi, mengidentifikasi dan menganalisis kekuatan, kelemahan, peluang dan ancaman SDM di bidang pemasaran batik khas Jambi, memilih dan menerapkan strategi yang tepat dalam meningkatkan sumber daya manusia dalam memasarkan batik khas Jambi. 


\section{Metode}

Desain penelitian ini adalah penelitian deskriptif kualitatif. Metode pengumpulan data dilakukan dengan menggunakan teknik wawancara terhadap responden dan studi pustaka terkait masalah tersebut. Dalam penelitian kualitatif istilah sampel diganti dengan judul partisipan atau informan. Penentuan jumlah partisipan dalam penelitian ini dilakukan dengan mengambil rule of thumb $1 / 3$ dari total populasi. Justifikasi ini diambil karena level analisis penelitian ini adalah unit organisasi. Kegiatan ini dilakukan di CV. Kreasi Asmah Batik, Olak Kemang, Danau Teluk, Jambi. Data yang digunakan dalam penelitian ini adalah data sekunder dan data primer. Data primer yang berkaitan dengan aspek sumber daya manusia yaitu pemilik usaha CV. Batik Kreasi Asmah, pengrajin batik dari CV. Batik Kreasi Asmah, aspek budaya, serta kreativitas dan strategi yang digunakan pengusaha dalam meningkatkan kapasitas sumber daya manusia dalam memasarkan batik Jambi yang mereka hasilkan. Data sekunder merupakan data yang dikumpulkan, meliputi data yang berkaitan dengan konsep dan bagaimana strategi peningkatan sumber daya manusia di bidang pemasaran menjadi motivasi bagi pengrajin di CV. Batik Kreasi Asmah untuk membangun keterampilan kewirausahaan secara internal. Data sekunder lainnya adalah data perkembangan batik Jambi hasil karya CV. Batik Kreasi Asmah serta mengidentifikasi berbagai permasalahan yang dihadapi terkait kapasitas pengembangan Sumber Daya Manusia (SDM) dalam meningkatkan sektor pemasaran.

Proses seleksi peserta sebelumnya diawali dengan mencari data karyawan pada CV. Batik Kreasi Asmah. Teknik pengambilan sampel lebih cocok jika menggunakan snowball sampling (bola salju), yaitu dengan mengumpulkan partisipan dari referensi ke suatu jaringan, asosiasi, kelompok, atau komunitas. Pertama, peneliti melakukan observasi lapangan dari total populasi 24 karyawan, namun setelah wawancara hanya ada 10 perwakilan, karena mampu memberikan penjelasan eksplisit, kemampuan berbicara, dan pernah menjadi duta sales di berbagai acara yang dihadiri oleh para pengusaha. Peneliti juga menggunakan 1/3 rule of thumb dari total populasi dengan justifikasi informasi yang diperoleh dari partisipan secara kualitatif mewakili populasi. Dalam menentukan partisipan penelitian, peneliti dibantu oleh seorang key person. Hal ini dimaksudkan untuk mengkaji secara langsung keadaan di lokasi penelitian melalui pengambilan gambar, pencatatan dan pencatatan fenomena yang terjadi di lapangan. Langkah selanjutnya adalah melakukan wawancara dengan narasumber dan pengurus penelitian yaitu:

1. Pemilik usaha (mendata langkah-langkah strategis yang dilakukan dalam peningkatan kapasitas SDM di CV. Batik Kreasi Asmah).

2. Pengrajin batik/karyawan CV. Batik Kreasi Asmah, (untuk mengetahui bagaimana strategi yang diterapkan karyawan dalam melaksanakan kinerja dan peningkatan kapasitas sebagai terobosan yang dilakukan dari waktu ke waktu).

3. Konsumen (untuk mengetahui bagaimana tanggapan konsumen terhadap peningkatan kapasitas sumber daya manusia yang dilakukan oleh pengusaha dan karyawan dengan tujuan kepuasan pelanggan sebagai bentuk keberhasilan pemasaran).

4. Instansi pemerintah yang terkait dengan pengembangan batik Jambi khususnya di CV. Batik Kreasi Asmah (untuk mengetahui jenis peraturan dan kebijakan tentang pengembangan kapasitas sumber daya manusia di bidang pemasaran yang dilakukan oleh pemerintah daerah).

Data kualitatif dari wawancara dianalisis dengan membuat transkrip wawancara, menuliskan secara cermat data dan informasi yang diperoleh dan menguranginya. Reduksi data dilakukan dengan membuat abstraksi yaitu mengambil dan mencatat informasi yang berguna sesuai dengan konteks kajian atau mengabaikan kata-kata yang tidak perlu, sehingga diperoleh intisari kalimat, tetapi menggunakan bahasa yang sesuai dengan bahasa informan. Abstrak tersebut kemudian dikelompokkan berdasarkan taksonomi dan domain penelitian. Analisis domain bertujuan untuk mendapatkan gambaran yang umum dan komprehensif tentang objek / penelitian atau situasi sosial dan mendeskripsikannya secara lebih rinci.

\section{Statistik Karakteristik Responden}

Partisipan dalam penelitian ini adalah pemilik usaha CV. Batik Kreasi Asmah yang berjumlah 2 orang (Ibu Asmah dan suaminya) serta 10 orang karyawan dan pengrajin. Dari data tersebut diketahui bahwa $78 \%$ partisipan berjenis kelamin perempuan (7 orang) dan $22 \%$ partisipan berjenis kelamin laki-laki ( 2 orang). Rentang usia peserta terdiri dari $34 \%$ berusia 35-50 tahun (3 orang), 56\% berusia 51-60 tahun (5 orang) dan 10\% berusia 61-70 tahun (1 orang). Dari keuntungan per / bulan terlihat bahwa bisnis ini masih termasuk dalam kategori bisnis makro karena perjalanan bisnis yang telah mencapai 8 tahun dengan keuntungan per / bulan sebesar 60 juta diperoleh dari bisnis yang sebelumnya telah dirintis. Oleh orang tua Ibu Asmah, maka yang dilakukan oleh Ibu Asmah adalah mempertahankan usahanya, memperluas pasar dan mencari strategi baru. 


\section{Identifikasi Lingkungan Internal-Eksternal (IE) CV. Batik Kreasi Asmah}

Tabel 1

Analisis Lingkungan CV. Batik Kreasi Asmah Jambi

\begin{tabular}{|c|c|}
\hline Strengths (Kekuatan) & Weaknesses (Kelemahan) \\
\hline $\begin{array}{l}\text { - Produk batik dengan kualitas baik, } \\
\text { melalui teknik produksi yang diarahkan } \\
\text { pada kualitas, contoh: penggunaan } \\
\text { warna-warna natura1). } \\
\text { - Motif pewarnaan unik yang tidak } \\
\text { mudah ditiru. } \\
\text { - } \quad \text { Harga batik relatif stabil. } \\
\text { - Sudah memiliki brand image bahkan } \\
\text { brand awareness di kalangan desainer } \\
\text { seperti Kiki Bakri Jambi. }\end{array}$ & $\begin{array}{l}\text { - } \begin{array}{l}\text { Saluran pema saran yang kurang } \\
\text { bervariasi. }\end{array} \\
\text { - } \text { Karyawan tidak memiliki disiplin waktu } \\
\text { dan jam kerja yang terukur. } \\
\text { - Ada jenis batik tulis (tulis) tertentu yang } \\
\text { harganya mahal, karena proses } \\
\text { pembuatannya dianggap sulit, memakan } \\
\text { waktu lama dan prose snya manual. } \\
\text { - Ketersediaan tenaga kerja masih terbatas } \\
\text { (terutama kaum muda). } \\
\text { - Sebagian pemenuhan bahan baku harus } \\
\text { diambil dari Jawa Tengah (Solo dan } \\
\text { Yogyakarta). } \\
\text { - Pengelolaan keuangan yang masih belum } \\
\text { berjalan optimal sehingga arus kas belum } \\
\text { dapat diprediksi. }\end{array}$ \\
\hline Opportunities (Peluang) & Threats (Ancaman) \\
\hline $\begin{array}{l}\text { - Permintaan batik sangat tinggi untuk } \\
\text { ekspor ke luar Jambi (Kalimantan, } \\
\text { Sulawesi, Batam) bahkan luar ne geri } \\
\text { (AS, Kanada, dan Jepang). } \\
\text { - Perkembangan trend fashion batik yang } \\
\text { membuka peluang pasar. } \\
\text { - Dukungan pemerintah dari sisi teknis } \\
\text { permodalan (akses kredit), pendidikan } \\
\text { dan pelatihan, serta berbagai kebijakan } \\
\text { mengenai aturan penggunaan batik } \\
\text { telah berjalan, terutama di dinas dan } \\
\text { juga di berbagai instansi pendidikan di } \\
\text { Provinsi Jambi. } \\
\text { E-commerce menciptakan peluang } \\
\text { untuk memasarkan secara online. } \\
\text { Dapat bersaing dengan industri batik di } \\
\text { tingkat global dengan karakteristik } \\
\text { yang unik. }\end{array}$ & $\begin{array}{l}\text { - Munculnya berbagai UMKM batik baru } \\
\text { Jambi dengan modal lebih besar. } \\
\text { - Adanya 'peniru' / duplikasi motif yang } \\
\text { telah dibuat (CV. Batik Kreasi A smah } \\
\text { belum menetapkan be berapa motif } \\
\text { uniknya menjadi HAKI). } \\
\text { - Hak paten yang ada tidak } \\
\text { mengakomodasi perlindungan hukum } \\
\text { atas motif batik yang ada. } \\
\text { - Bersaing dengan B atik Jambi' yang } \\
\text { diproduksi di luar Jambi dan juga 'Batik } \\
\text { Luar Jambi' yang memasuki pasar batik } \\
\text { di Jambi. } \\
\text { Pekerja muda lebih memilih bekerja di } \\
\text { sektor industri skala besar (pabrik) atau } \\
\text { perkantoran daripada menjadi pengrajin } \\
\text { atau karyawan "home industry". } \\
\text { Batik cap "printing" yang dijual dengan } \\
\text { harga murah. }\end{array}$ \\
\hline
\end{tabular}

Sumber: data olahan

\section{Strategi Bisnis dan Pemasaran Batik Jambi (CV. Batik Kreasi Asmah)}

Setelah mengevaluasi perhitungan skor faktor internal dan eksternal, langkah selanjutnya adalah memasukkan skor tersebut ke dalam matriks IE (Internal-Eksternal). Matriks ini digunakan untuk menentukan posisi bisnis CV. Batik Kreasi Asmah Jambi di pasaran menunjukkan bahwa posisi CV. Batik Kreasi Asmah berada di tengah daya tarik pasar kelas menengah dan persaingan. Kondisi ini menunjukkan tumbuhnya industri batik CV Kreasi Batik Asmah dengan mengincar penguasaan pangsa pasar. Hal ini dikarenakan batik masih banyak diminati oleh konsumen, dipakai sebagai pakaian pada acara formal maupun non formal, baik pria maupun wanita segala usia dapat mengenakan batik. Apalagi pemerintah Indonesia telah menetapkan hari batik nasional. Pertumbuhan pasar yang berada pada posisi stabilitas harus membutuhkan identifikasi segmen pasar. Pasalnya, hampir di berbagai daerah di Jambi telah dihasilkan kain batik dengan keunikannya masing-masing, seperti batik Sungai Penuh. Demikian CV. Batik Kreasi Asmah harus menerapkan strategi diferensiasi yang dapat diklasifikasikan menjadi diferensiasi produk dalam pemasaran dan segmentasi kelas (bawah, menengah, atas), dengan menyasar konsumen kelas menengah ke atas, sehingga harga jual yang relatif mahal harus diimbangi dengan kualitas. produk. Selain itu, pemilihan spesialisasi produk dapat menjadi salah satu alternatif strategi untuk membidik pangsa pasar. Hal tersebut sesuai dengan yang dilakukan oleh CV. Kreasi Batik Kreasi Asmah dengan spesialisasi batik tulis dengan pewarnaan natural, dengan gradasi warna yang lengkap.

Pada posisi pasar persaingan menengah ini, perlu dilakukan investasi selektif. Salah satu caranya adalah dengan mengembangkan pasar dan meningkatkan aktivitas bisnis. Mengembangkan pasar dapat dilakukan dengan melakukan segmentasi pasar dan produk, sedangkan peningkatan kegiatan usaha hanya dapat dilakukan jika pengusaha CV. Batik Kreasi Asmah bekerjasama dengan karyawannya. Karyawan adalah mitra berharga yang dapat diajak berpikir, berdiskusi, dan berlatih untuk menemukan ide-ide baru. Tidak hanya sebatas pekerja borongan yang dibutuhkan saat pesanan berlebihan. Oleh karena itu, diharapkan para pekerja di industri batik Jambi tertarik menjadi pengrajin batik atau jika tidak memiliki kemampuan membatik dapat mengikuti pemasaran, pengaturan dokumen, pengarsipan dan membantu pencatatan keuangan. Dukungan teknologi saat ini menjadi peluang CV. Batik Kreasi Asmah tidak hanya teknologi produksi tetapi juga teknologi komunikasi dan informasi. Kelemahan CV. Batik Kreasi 
Asmah sulit untuk mempercayakan pengelolaan administrasi, keuangan dan pemasaran kepada siapapun selain anggota keluarga. Kelemahan ini membuat CV. Batik Kreasi Asmah seringkali dinilai kurang memiliki kualitas sumber daya manusia yang baik. Setelah mengetahui posisi bisnis CV. Pada pasar Batik Kreasi Asmah, langkah selanjutnya adalah mengidentifikasi alternatif strategi bisnis dan pemasaran yang dapat dilakukan dengan menghitung skor masing-masing untuk elemen lingkungan internal-eksternal, seperti pada Tabel 2.

Tabel 2

Strataegi EFAS - IFAS

\begin{tabular}{|l|l|l|}
\hline EFAS / IFAS & Strengthes (S) & Weaknesses (W) \\
\hline Opportunities (O) & SO Strategy & WO Strategy \\
& $1.87+1.53=3.4$ & $0.60+1.51=2.11$ \\
\hline Threats (T) & Strategy ST & WT Strategy \\
& $1.88+0.75=2.63$ & $0.59+1.78=2.37$ \\
\hline
\end{tabular}

Sumber : Data Diolah.

Dari Tabel 2, alternatif strategi bisnis yang dapat dilakukan oleh CV. Batik Kreasi Asmah adalah:

1. Pertama, strategi SO dengan skor tertinggi 3,4 artinya pelakunya adalah CV. Kreasi Batik Asmah harus menciptakan strategi yang memanfaatkan kekuatan untuk memanfaatkan peluang, antara lain motif batik yang unik, gradasi warna yang berbeda untuk setiap motifnya, teknik membatik yang mampu menciptakan bahan berkualitas yang tahan lama, tidak mudah luntur, dan pewarnaan yang menggunakan bahan natural. materi dan memiliki perkumpulan Klaster Batik Jambi yang semestinya dapat mendukung para pelaku UMKM Batik Jambi yang rata-rata skalanya masih mikro.

2. Kedua, strategi ST dengan skor 2,63 menggunakan kekuatan CV. Batik Kreasi Asmah dan daya tariknya untuk mengatasi ancaman yang dihadapinya. Beberapa langkah yang dapat dilakukan adalah merekrut tenaga kerja tidak hanya di sekitar tempat usaha, tetapi juga di daerah lain dengan syarat memiliki minat dan minat untuk menjadi pengrajin batik, terjalin kerjasama antara usaha mikro dan usaha menengah. membuka akses pasar yang lebih luas, melakukan promosi secara online dan memperbanyak reseller dari luar kota jambi (seperti di kerinci, tanjung jabung timur dan barat, muaro jambi, batanghari dan kabupaten lainnya), mencoba mendaftarkan hak paten motif motif itu menghasilkan. Sedangkan batik natural bisa dimulai dengan mengedukasi konsumen bahwa batik natural adalah batik yang ramah lingkungan karena menggunakan pewarna alami, limbah produksinya tidak mencemari lingkungan dan tidak luntur. Edukasi ini perlu dilakukan karena terkadang konsumen tidak mau membeli batik natural karena warna batik terlihat kurang cerah. Untuk menjaga ketersediaan bahan pewarna alami, CV. Batik Kreasi Asmah dapat memotivasi masyarakat setempat untuk menanam indigo (sejenis tanaman pewarna alami), bekerja sama dengan petani setempat.

3. Ketiga, strategi WT dengan skor 2,37. Strategi ini dilakukan dengan meminimalisir kelemahan CV. Batik Kreasi Asmah untuk menghindari ancaman yang datang. Beberapa langkah dapat ditempuh dengan meningkatkan loyalitas pengrajin batik dengan memberikan paket kompensasi yang lebih menarik (diluar gaji), memberikan kesempatan kepada pengrajin yang tergabung dalam CV. Batik Kreasi Asmah, selain sebagai karyawan untuk bertukar pikiran, masukan, dan pendapat terkait kegiatan produksi, menjadikan para tenaga kerja memiliki persepsi bahwa pemilik usaha memperlakukan karyawan secara manusiawi. Selain itu juga harus disadari bahwa keberhasilan pengelolaan bisnisnya akan sangat terbantu dengan keterlibatan karyawan dalam pengelolaannya. Jadi, untuk pekerjaan tertentu yang tidak membutuhkan keahlian di bidang batik, bisa dilakukan karyawan lain. Misalnya pengendalian administrasi, keuangan, pengelolaan bahan baku, dan pembuatan media promosi dapat dilakukan oleh karyawan lain. Uraian tugas sangat dibutuhkan oleh pelaku usaha untuk profesionalisme kerja. Kelemahan utama manajemen batik di Jambi CV. Kreasi Batik Kreasi adalah pemilik yang menjalankan usahanya sendiri, enggan membagi pengelolaannya dengan karyawan.

4. Keempat, strategi WO dengan skor 2,11. Strategi ini dilakukan dengan meminimalisir kelemahan CV. Batik Kreasi Asmah untuk memanfaatkan peluang yang ada. Beberapa langkah yang dapat ditempuh dalam 'bidang pemasaran' dengan memanfaatkan sumber daya manusia yang ada antara lain mengupayakan promosi online melalui media sosial (web, facebook, twitter, instagram dan lain-lain). Hal tersebut perlu dilakukan karena permintaan batik masih cukup stabil dan cenderung meningkat. Apalagi batik Jambi belum banyak dikenal oleh konsumen di luar Jambi sehingga promosi penting dilakukan. CV. Batik Kreasi Asmah sudah berusaha merambah dunia online meski masih dikuasai oleh para pengusaha, karena karyawan dinilai belum mampu melakukan model pemasaran start up, sehingga bisnis batik ini lebih cenderung seperti one man enterprise, yang semuanya pekerjaan mulai dari desain motif, belanja bahan, manajemen keuangan, pameran. dan dilakukan oleh pengusaha CV. Batik Kreasi Asmah Jambi. 
Di sisi lain, meningkatnya jumlah pendatang yang berkiprah di pasar Jambi akan menjadi ancaman tersendiri. Hal tersebut dapat diatasi dengan membuat usaha batik Asmah yang juga pemasarannya ke daerah lain (di luar Jambi). Menambahkan saluran pemasaran yang bervariasi untuk mempromosikan produk batik. Biaya produksi yang tinggi untuk jenis batik tertentu harus diefisienkan kembali dengan meminimalisir bahan yang terbuang percuma, mencari distributor yang kompetitif, menentukan target kerja karyawan di bidangnya masing-masing (pengrajin, pengelola administrasi dan keuangan) agar biaya tenaga kerja tidak terbuang percuma dan menjadi lebih disiplin. . Dengan adanya tanggung jawab pekerjaan, peralatan harus digunakan sesuai dengan kebutuhan dan pemeliharaan yang diperlukan, agar peralatan tersebut tetap memiliki masa pakai yang tepat. Dukungan dari pemerintah berupa permodalan (akses kredit) dan pelatihan dapat dimanfaatkan oleh pemilik untuk mengikutsertakan pengrajin dalam program pelatihan, baik bagi pengrajin baru maupun pengrajin lama. Pengrajin tua perlu meningkatkan keterampilan membatik agar setiap tahun selalu ada pengembangan keterampilan. Karyawan yang menunjukkan hasil setelah mengikuti pelatihan akan diberikan bonus tersendiri (tidak termasuk gaji). Begitu pula dengan karyawan yang mampu menciptakan kreativitas dan inovasi dalam metode pemasaran, misalnya dengan model kemitraan dan partisipasi pemasaran melalui kerjasama dengan distributor dan akses kredit dan dana CSR perusahaan untuk mendukung pemasaran batik otentik Jambi.

\section{Penerapan Strategi Pengembangan Sumber Daya Manusia Bidang Pemasaran CV. Batik Kreasi Asmah}

Hasil analisis SWOT dan penentuan strategi bisnis batik Jambi pada CV. Batik Kreasi Asmah Kota Jambi, dapat disimpulkan bahwa faktor SDM merupakan kendala tersendiri dalam pengelolaan manajemen bisnis bisnis dan pemasaran pada CV. Batik Kreasi Asmah. Manajemen sumber daya manusia pada CV. Batik Kreasi Asmah sangat penting agar bisnis yang didirikan tidak bangkrut. Ketersediaan sumber daya manusia dari segi kuantitas dan kualitas berdampak pada lemahnya pengelolaan usaha dan pemasaran batik yang dilakukan oleh CV. Batik Kreasi Asmah yang membuat kagum usaha satu orang. Oleh karena itu, diperlukan strategi pengembangan SDM untuk meningkatkan manajemen bisnis dan pemasaran CV. Batik Kreasi Asmah. Disamping manajemen bisnis dan pemasaran yang baik, lama kelamaan akan menciptakan daya saing CV. Batik Kreasi Asmah. Strategi perencanaan ini meliputi:

1. Tahap Perekrutan, kegiatan rekrutmen dan seleksi yang berpedoman pada kualifikasi SDM yang dibutuhkan. Kualifikasi yang dibutuhkan terdiri dari kualifikasi umum dan khusus. Kualifikasi umum yaitu kebutuhan akan sumber daya manusia yang dapat digunakan secara umum untuk segala jenis kegiatan usaha dan pemasaran, seperti pengetahuan umum, kesehatan, kepribadian yang baik, kecerdasan, keseriusan, komitmen dan umur. Kualifikasi khusus yaitu kebutuhan sumber daya manusia yang hanya dibutuhkan untuk jenis pekerjaan tertentu (tidak semua orang dapat mengerjakannya), seperti keterampilan membatik, keterampilan berhitung, keterampilan operasional komputer dan lain sebagainya. Rekrutmen dan seleksi CV. Kreasi Batik Kreasi Asmah harus memperhatikan pekerja yang memiliki ketrampilan membatik. Namun ketrampilan tersebut juga harus didukung oleh kecintaan terhadap batik dan keinginan untuk melestarikan warisan budaya Indonesia (sense of belonging). Tenaga kerja yang direkrut berdasarkan kualifikasi umum dan khusus akan menempatkan karyawan sesuai dengan bidang keahliannya.

2. Tahap Pelatihan dan Pengembangan, perubahan lingkungan akan selalu terjadi dan jika CV. Batik Kreasi Asmah tidak bisa beradaptasi dengan perubahan lingkungan, maka lama kelamaan usahanya akan menderita. Pemilik CV. Batik Kreasi Asmah harus mau menyadari bahwa investasi di bidang SDM merupakan hal yang mutlak harus dilakukan jika ingin terus eksis. Jika tidak ada keturunan di keluarganya yang memiliki bakat membatik, niscaya mereka harus melatih tenaga kerja yang bisa dipercaya dan memiliki visi dan rindu yang sama dengan pemiliknya. Jenis pelatihan dan pengembangan yang dibutuhkan antara lain: Pelatihan yang berkaitan dengan teknik membatik, seperti membatik, membuat prangko, mewarnai, mewarnai, pelatihan membuat motif, seperti mencari ide, menggambar dan melihat dari segi estetika, pelatihan di luar itu. terkait dengan pembuatan batik, seperti pengelolaan keuangan dan administrasi, pemasaran online, pembuatan iklan dan promosi. Bagian utama dari tahapan ini adalah bagaimana karyawan memiliki kemampuan berwirausaha sehingga CV. Batik Kreasi Asmah bisa dipertahankan. Tentunya harus diimbangi dengan berbagai keputusan dan kebijakan dalam mengembangkan 'promosi apa yang ingin Anda tuju', apakah harus start up, atau lebih konvensional dengan menentukan segmen pasar yang dibidik.

3. Tahap Perencanaan Karir, kecenderungan anak muda sekitar yang tidak mau menjadi pengrajin batik karena pertama tidak ada minat, kedua pekerjaan ini dianggap kurang bergengsi dan kurang sosial dan ketiga tidak ada prospek karir kedepannya. Menurut mereka, orang di luar keturunan keluarga pemilik tidak akan memiliki karier yang kokoh. Padahal, karir yang mapan merupakan cerminan dari peningkatan kesejahteraan rakyat. Perencanaan karir bagi karyawan batik dapat dilakukan dalam tiga tahap, yaitu: 
a. Tahap Perencanaan, fase ini menyelaraskan desain karir karyawan dengan pemiliknya. Tujuan tahap ini adalah untuk mengidentifikasi kekuatan dan kelemahan karyawan serta membantu karyawan memilih jalur pengembangan karir. Pada tahap ini perlu dibangun pemahaman tentang bagaimana mengidentifikasi kekuatan dan kelemahan dalam sebuah tim, bersinergi sesuai dengan bakat dan kemampuan karyawan, kemampuan menggambar, membuat pola, membatik, memadukan warna, mewarnai, finishing, promosi. dan penjualan produk dan organisasi. Kemampuan yang berbeda ini harus diantisipasi dengan saling melengkapi kekurangan satu sama lain dalam kerja tim. Talenta multi talenta juga menjadi catatan penting untuk merencanakan jalur karir di fase ini.

b. Tahap Pengarahan, fase ini membantu karyawan menetapkan jenis karier yang mereka inginkan. Karena berbeda dengan sektor industri dan perusahaan berskala besar, maka diperlukan kemampuan pengusaha untuk mengarahkan pilihan karir karyawan kedepannya. Ada tiga jalur karir alternatif, yaitu menjadi pengrajin batik selamanya, yang kedua berkembang menjadi pengusaha batik, dan tiga karir di bidang manajerial. Bagi karyawan yang memiliki keterampilan membatik sangat baik dapat diarahkan untuk memilih karir menjadi supervisor senior tetap atau memiliki minat untuk membuka usaha batik sendiri.

c. Tahap Pengembangan, tahap ini membantu karyawan untuk menciptakan kreativitas yang dapat mendukung mereka memasuki karir baru di masa depan. Misalnya jika ada karyawan yang berminat membuka usaha sendiri, maka wirausahawan berperan sebagai mentor bagi karyawannya dengan memberikan bimbingan, nasehat, memberikan informasi pelatihan, pinjaman modal, peluang usaha dan lain sebagainya, bahkan menghubungkan karyawan dengan karyawannya. akses ke dana seperti perbankan, atau Departemen. Koperasi \& UKM, koperasi, pemerintah kota, pemilik butik, desainer, lain-lain.

4. Sistem Kompensasi, segala sesuatu yang diterima karyawan sebagai imbalan atas kontribusinya disebut sebagai kompensasi. Pengusaha CV. Batik Kreasi Asmah harus menetapkan kompensasi dengan syarat yang adil dan pantas. Kompensasi seringkali menjadi faktor pendorong utama seseorang untuk bekerja. Kompensasi dapat berupa material dan non-material. Kompensasi material biasanya diberikan dalam bentuk uang, berupa gaji, bonus, tunjangan dan lain-lain. Sedangkan kompensasi non material dapat diberikan dalam bentuk penghargaan, pujian atau pengakuan sosial atas kinerjanya. Kompensasi tenaga kerja yang rendah bagi pengrajin batik dapat menjadi ancaman serius bagi kelangsungan usaha dan pemasaran batik. Sedangkan besarnya kompensasi sangat ditentukan oleh keuntungan bisnis dan akan sangat mempengaruhi loyalitas, kepuasan kerja, motivasi, dan disiplin.

- Sistem Keluaran : Kompensasi ditentukan tergantung pada unit yang diproduksi oleh pekerja (per satuan, per meter, per liter, per kilogram). Keunggulan sistem ini adalah karyawan dengan sungguh-sungguh mencapai target dengan kualitas yang terjamin.

- Sistem Volume : Kompensasi karyawan dibayarkan berdasarkan ukuran volume pekerjaan dan lamanya waktu yang dibutuhkan untuk menyelesaikan pekerjaan. Pilihan ini juga diterapkan oleh CV. Batik Kreasi Asmah, karena jika pesanan berlebih karena jumlah karyawan tetapnya dibatasi sekitar 10 pengrajin. Namun kelemahan dari sistem ini adalah sulitnya menjaga kualitas produk karena sulitnya pengawasan yang dilakukan. Namun lebih dari itu, pengrajin kontraktor menjadi mitra yang berada di bawah bimbingan mentor (coaching).

- Sistem Waktu : Kompensasi karyawan dibayarkan berdasarkan waktu standar (jam, hari, minggu, bulan). Sistem ini lebih tepat untuk karyawan dengan jenis pekerjaan yang tidak memiliki standar fisik kuantitatif, misalnya karyawan di bagian administrasi, keuangan, promosi dan lain-lain. Dan sistem kali ini tidak dapat diterapkan oleh CV. Batik Kreasi Asmah, karena seluruh sektor pengelolaan masih berpusat pada wirausaha.

\section{Simpulan}

Hasil penelitian diatas dapat disimpulkan bahwa:

a. CV. Batik Kreasi Asmah berada pada posisi stabilitas yaitu pada daya tarik pasar menengah dan persaingan pasar kelas menengah. Potensi pertumbuhan yang relatif tinggi masih menjadi daya tarik bisnis ini, terutama terus menggarap model bisnis dan start up marketing.

b. Hasil analisis SWOT yaitu faktor kekuatan CV. Batik Kreasi Asmah yaitu produk yang berkualitas dan teknik membatik yang baik serta kekhasan motif unik yang menjadi keunikan tersendiri Faktor kelemahannya ketersediaan tenaga kerja yang masih terbatas, disiplin kerja yang kurang dan pengelolaan keuangan yang buruk. Faktor peluangnya adalah meningkatnya daya beli dan minat terhadap produk batik, meski belum dikatakan signifikan dari sisi hasil penjualan. Dan faktor ancamannya adalah semakin banyak usaha sejenis yang berasal dari luar daerah Jambi bahkan diproduksi di Jawa dan dijual ke Jambi serta pemain baru yang memiliki modal lebih. 
c. Model rekruitmen SDM dalam bisnis dan pemasaran di CV. Batik Kreasi Asmah masih memiliki kendala dengan keterbatasan kemampuan sumber daya manusia, usia yang tidak produktif dan ancaman pilihan variasi pekerjaan yang dinilai lebih menjanjikan, seperti perusahaan, mall, dan perkantoran swasta. Peneliti belum menemukan desain pemasaran yang terukur, selain menggunakan model pemasaran konvensional: membuka gerai, mengikuti pameran skala lokal dan nasional, dan tempat pelatihan sederhana. Pemasaran start-up belum ditanggapi dengan serius, meski profilnya telah dimuat di Majalah Garuda Indonesia pada tahun 2015.

\section{Daftar Pustaka}

Anisyah, Y. 2011. Analisis Perkembangan Industri Batik Semarang. Skripsi yang tidak dipublikasikan. Semarang : Fakultas Ekonomika dan Bisnis, Universitas Diponegoro.

Anonim, 15 Mei 2016. Jual Batik Jambi. Harian Online Jambi Ekspres.

Azmiah. 15 Oktober 2017. Indepth Interview.

Bangun, Wilson. 2012. Manajemen Sumber Daya Manusia. Jakarta: Erlangga.

Dinas Perindustrian dan Perdagangan Provinsi Jambi. 2016. Innovation System the Batik Jambi as A Competitive Product Road-Map.

Jacoeb Soemardjo. 2005. Modern Miring, dalam Denys Lombart, Nusa Jawa: Silang Budaya, Jakarta: Gramedia Utama.

Jain Kotler dan Suvit Maesincee. 2000. Holistic Marketing Concept dalam Marketing Move, A New Approach to Profit, Growth, and Renewal. Boston: Havard Business School Press.

Jazuli Akhmad, 2002. Metodologi Penelitian Bisnis. Yogyakarta: STIE Widya Wiwaha.

Lea, 2015. Jambi Perlu Tangkap Peluang Industri Kerajinan Batik. Berita Daerah Sumatera

Marzuki, 2005, Metodologi Riset, Yogyakarta: Ekonisia.

M. Rahmat. 30 Desember 2010. Industri Batik Jambi Kian Menyusut. Harian Online Tribun Jambi.

Mohammad. Metodologi Penelitian Ekonomi Islam, Pendekatan Kuantitatif. Yogyakarta: UPFE-UMY, 2005).

Nani.15 Mei 2010. Industri Batik Jambi Kian Menyusut. Harian Online Kompas.

Ratu Munawaroh Zulkifli, 15 Mei 2016. Batik Jambi. http://photojambi.com/batik-jambi/.

Santosa Doellah. 2002. Batik Pengaruh Zaman dan Lingkungan. Surakarta: Danar Hadi.

Sugiyono. 2008. Metode Penelitian: Kuantitatif, Kualitatif dan R\&D. Bandung: Alfabeta.

Suharsimi Arikunto, 1996. Prosedur Penelitian Suatu Pendekatan Praktik. Edisi Revisi. VI Jakarta: Rineka Cipta.

Supardi. 2005. Metodologi Penelitian Ekonomi dan Bisnis. Yogyakarta: UII Press.

Swari Utami Dewi. 5 November 2008. Batik: Warisan Leluhur yang Patut Dipertahankan. Radar Banjarmasin.

Gunartha, M. 2013. 10 Tantangan Ketika Mengelola SDM pada Bisnis UKM. http://mediabisnisonline.com/10tantangan-ketikamengelola-sdm-pada-bisnis-ukm/ diakses tanggal 8 November 2017.

Hu, W, M. 2010. SMES and Economic Growth: Entrepreneurship or Employment. ICIC Express Letters. Vol. 4, No. 6, December.

Nurainun, Heriyana \& Rasyimah. 2008. Analisis Industri Batik di Indonesia. Fokus Ekonomi (FE). Desember, Vol. 7 , No. 3, pp: 124-125.

Partomo, T. S. 2004. Usaha Kecil Menengah dan Koperasi. Working Paper Series. No. 9, Juni.

Savlovschi, L. I \& Robu, N. R. 2011. The Role of SMES in Modern Economy. Economia, Seria Management. Vol 14, Issue 1.

Sriyana, J. 2010. Strategi Pengembangan Usaha Kecil dan Menengah (UKM): Studi Kasus di Kab. Bantul. Simposium Nasional 2010, Menuju Purworejo Dinamis dan Kreatif. pp: 79-103.

Widajanti, E. 2007. Perencanaan Sumber Daya Manusia yang Efektif: Strategi Mencapai Keunggulan Kompetitif. Jurnal Ekonomi dan Kewirausahaan. Vol. 7, No. 2, pp: 105-114.

Wulansari, Ariani Nury, dkk. tt. Strategi Perencanaan SDM untuk Peningkatan Daya Saing UKM Batik Semarang. Prosiding Seminar Nasional Multi Disiplin Ilmu and Call for Papers UNISBANK (SENDI_U): Kajian Multi Disiplin Ilmu untuk mewujudkan Poros Maritim dalam Pembangunan Ekonomi Berbasis Kesejahteraan Rakyat. ISBN: 978-979-3649-81-8. 